\title{
A Novel Investigation and Comparative Study on Building Integrated Photovoltaic Thermal (BIPVT) System
}

\author{
Amit Kumar Dash*, Sanjay Gairola \\ Department of Electrical \& Electronics Engineering \\ Noida Institute of Engineering and Technology, Greater Noida, Uttar Pradesh, India \\ "Corresponding author: amitkudash@ rediffmail.com \\ Sanjay Agrawal \\ School of Engineering and Technology \\ Indira Gandhi National Open University (IGNOU), New Delhi, India \\ Shweta Shukla \\ Department of Electrical Engineering \\ Meerut Institute of Engineering and Technology, Meerut, Uttar Pradesh, India
}

(Received April 24, 2018; Accepted November 28, 2018)

\begin{abstract}
An analysis of BIPVT system has been carried out in this paper based on arrays named as solar cell tile array and semitransparent array. Previously comparisons and performance analysis were carried out for opaque and semitransparent system in non-optimized way but in the present case it has been optimized to get better results. As far as energy efficiency and exergy is concerned semitransparent PVT has an edge as compared to others in all respect. Semitransparent PVT has higher useful energy gain by $2.5 \mathrm{KWH}$ as compared to SCT. Further the electrical and thermal efficiency has been derived and a conclusion has been made that semitransparent PV cell has an edge in all respects as compared to SCT. The electrical efficiency has been increased to $17.17 \%$ from the previous $16 \%$ and overall exergy to $18.4 \%$ from previous $17.1 \%$. i.e. an overall growth of $6.8 \%$ and $7.6 \%$ respectively.
\end{abstract}

Keywords-SCT \& semitransparent PVT array, Building integrated photovoltaic system (BIPVT), Photovoltaic (PV), Exergy.

\section{Introduction}

In recent times solar thermal systems are widely used, but PVTs are not used extensively. More than $80 \%$ of the incoming solar energy is either reflected or absorbed as heat energy. Loferski et al. (1998) studied and obtained few results related to the system with air circulation in a housing. Agrawal and Tiwari (2009) concluded that in terms of energy saving glazed hybrid gives better result as compared to normal PV module. Vats and Tiwari (2012) provided various data of the efficiency of different types of material out of which one can select. He et al. (2006) used the Hybrid Photovoltaic and Thermal (PVT) collector technology using water as the coolant as a solution for improving the energy performance. The BIPVT system designed by (Agrawal and Tiwari, 2010) have shown that the roof top placed in an effective area of $65 \mathrm{~m}^{2}$, is capable of producing the net electrical and thermal exercise of $16,300 \mathrm{kWh}$ and $1550 \mathrm{kWh}$, respectively, at an overall thermal efficiency of $54.2 \%$. Kim and Kim (2012) have studied simulation of air-type building-integrated photovoltaic-thermal system. Singh et al. (2015) described the modeling and optimization of single channel system by genetic algorithm. The scheme proposed by Singh et al. (2016) made a comparative study of exergy of different cities and concluded that there is an increment of 5.8 to 
International Journal of Mathematical, Engineering and Management Sciences

Vol. 4, No. 2, 460-470, 2019

https://dx.doi.org/10.33889/IJMEMS.2019.4.2-038

$14.7 \%$ of exergy as compared to proposed by Agrawal and Tiwari (2012) using soft computing technique.

\section{Thermal Modeling of BIPVT System}

In the current paper research has been made on cold climatic condition of India by placing the designed model on the roof top of the building. Rajoria et al. (2012) described the overall energetic heat gain and exergy heat gain and overall efficiency of different city for summer condition.

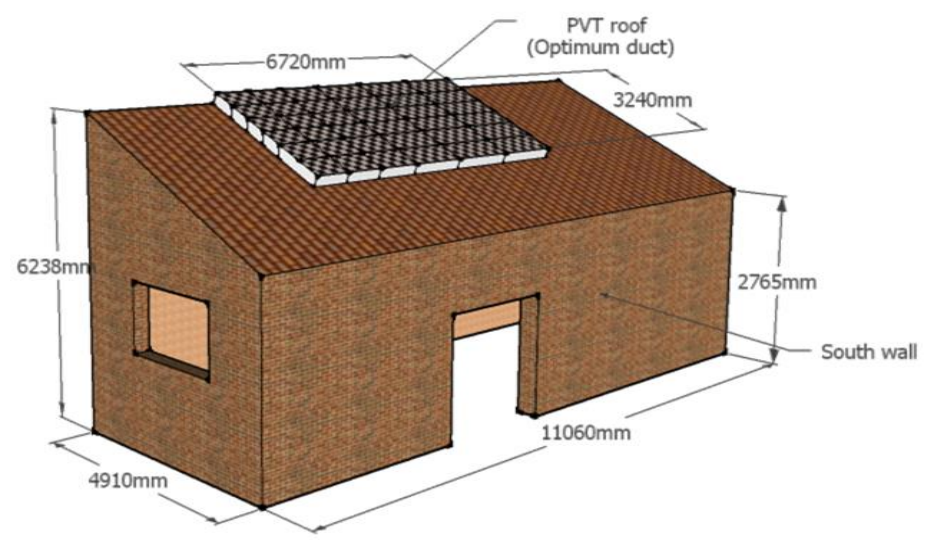

Figure 1. Perspective view of proposed building integrated photovoltaic thermal (BIPVT) system installed at the roof of the building

Rajoria et al. (2013) made an attempt to analyse the performance of semi-transparent hybrid photovoltaic thermal double pass facades (HPVT-DPF) connected in series and parallel in terms of energy and exergy for four weather conditions of Srinagar. Figure 1 shows the prospective view of the designed model with specification of the proposed system. As Srinagar is located at 3401'N, $74^{0} 51^{\prime} \mathrm{E}$ due to which the propose systems is fitted in the south direction inclined at an angle of the latitude of that city i.e. $35^{0}$ to the horizontal. With proposed area of $65 \mathrm{~m}^{2}$ the present system has 48 PV Module in 6rows.

Table 1. Specification of proposed system

\begin{tabular}{|c|c|}
\hline $\mathrm{V}_{\max }$ & $425 \mathrm{~V}$ \\
\hline$\eta$ & $17.1 \%$ \\
\hline Size of room & $5580 \mathrm{~mm} \times 4910 \mathrm{~mm}$ \\
\hline Side wall height & $2765 \mathrm{~mm} \times 6238 \mathrm{~mm}$ \\
\hline Roof area & $11060 \mathrm{~mm} \times 6144 \mathrm{~mm}$ \\
\hline Roof inclination & $35^{0}$ \\
\hline
\end{tabular}

Table 1 gives the detail specification of the output voltage and room specification. 
International Journal of Mathematical, Engineering and Management Sciences

Vol. 4, No. 2, 460-470, 2019

https://dx.doi.org/10.33889/IJMEMS.2019.4.2-038

Table 2. Design parameters of proposed system

\begin{tabular}{|c|c|}
\hline Design parameters & Corresponding values \\
\hline Length of proposed system & $1650 \mathrm{~mm}$ \\
\hline Width of proposed system & $800 \mathrm{~mm}$ \\
\hline Net output & $155 \mathrm{~W}$ \\
\hline Depth of propose Duct & $255 \mathrm{~mm}$ \\
\hline channel & single pass channel \\
\hline $\mathrm{C}_{\text {air }}(\mathrm{J} / \mathrm{kg} \mathrm{K})$ & 1005 \\
\hline $\mathrm{C}_{\mathrm{r}}$ & 0.38 \\
\hline $\mathrm{h}_{0}\left(\mathrm{~W} / \mathrm{m}^{2}\right)$ & $5.70+3.8 \times \mathrm{V}_{\mathrm{a}}$ \\
\hline $\mathrm{h}_{\mathrm{i}}\left(\mathrm{W} / \mathrm{m}^{2}\right)$ & 2.8 \\
\hline $\mathrm{h}_{\mathrm{T}}\left(\mathrm{W} / \mathrm{m}^{2}\right)$ & $2.80+3 \times$ vair \\
\hline $\mathrm{K}_{\mathrm{c}}\left(\mathrm{W} / \mathrm{m}^{2}\right)$ & 0.040 \\
\hline $\mathrm{K}_{\mathrm{G}}\left(\mathrm{W} / \mathrm{m}^{2}\right)$ & 0.80 \\
\hline $\mathrm{K}_{\mathrm{i}}\left(\mathrm{W} / \mathrm{m}^{2}\right)$ & 0.0350 \\
\hline $\mathrm{K}_{\mathrm{T}}\left(\mathrm{W} / \mathrm{m}^{2} \mathrm{~K}\right)$ & 0.380 \\
\hline $\mathrm{L}_{\mathrm{c}}(\mathrm{mm})$ & 0.3 \\
\hline $\mathrm{L}_{\mathrm{G}}(\mathrm{mm})$ & 34 \\
\hline $\mathrm{L}_{\mathrm{i}}(\mathrm{mm})$ & 11 \\
\hline $\mathrm{L}_{\mathrm{T}}(\mathrm{mm})$ & 3 \\
\hline$\alpha_{c}$ & 0.7 \\
\hline$\alpha_{t}$ & 0.7 \\
\hline$\beta_{\mathrm{c}}$ & 0.9 \\
\hline$\eta_{\mathrm{c}}$ & 0.16 \\
\hline$i_{g}$ & 0.85 \\
\hline$\rho_{\mathrm{a}}\left(\mathrm{kg} / \mathrm{m}^{3}\right)$ & 1.29 \\
\hline
\end{tabular}

Table 2 gives the detail values of the design parameters of the proposed system.

To calculate electrical efficiency of any PV cell as Zondag et al. (2002) designed a theory is given by,

$\eta_{c a}=\eta_{\text {ref }}\left[1-\Phi_{\text {ref }}\left[T_{c}-T_{a}\right)\right]$

Quantities $\eta_{\text {ref }}, T_{\mathrm{a}}$ and $\varphi_{\text {ref }}$ are usually references to what the researcher has to set accordingly.

$$
E_{\text {out }}=\eta_{c a} * I(t) * b L * n_{p v}
$$

Equivalent thermal energy of electrical is given by

$$
E_{e t h}=\frac{E_{\text {out }}}{C_{f}}
$$

Adding thermal gain of the proposed systems to equivalent thermal energy of electrical energy overall thermal energy of proposed system can be calculated as,

$$
Q_{\text {hourly }}=\frac{E_{\text {out }}}{C_{f}}+Q_{u}
$$


International Journal of Mathematical, Engineering and Management Sciences

Vol. 4, No. 2, 460-470, 2019

https://dx.doi.org/10.33889/IJMEMS.2019.4.2-038

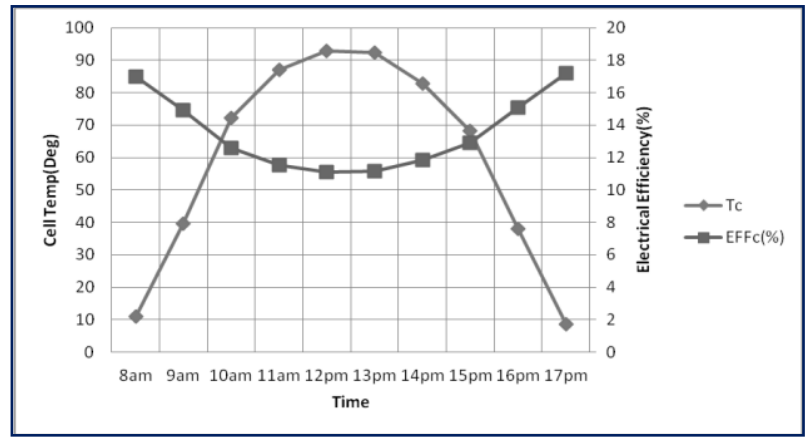

Figure 2. Comparison between cell temperature and electrical efficiency w.r.t time

The overall thermal energy of the proposed system can be derived by

$Q_{\text {daily }}=\sum_{j=1}^{n} \frac{\left(\eta_{c a}\right)_{j} *[I(t)]_{j} * b L * \eta_{p v}}{C_{f}}+\sum_{j=1}^{n}\left(Q_{u}\right)_{j}$

Overall thermal efficiency can be derived as,

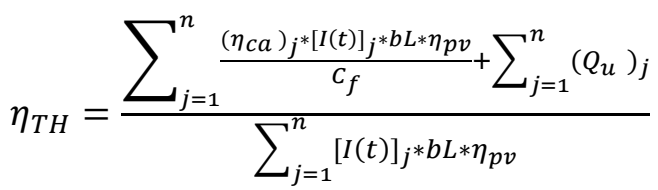

Thermal Exergy $=Q_{u}\left(1-\frac{T_{a}}{T_{\text {airout }}}\right)$

Net Exergy Gain $=E_{\text {out }}+Q_{u}\left(1-\frac{T_{a}}{T_{\text {airout }}}\right)$

Energy balance equation of the proposed model is given by:

$\left[\begin{array}{c}\text { Rate of heat } \\ \text { received by } \\ \text { solar cell }\end{array}\right]+\left[\begin{array}{c}\text { Rate of heat } \\ \text { received by } \\ \text { non packing area }\end{array}\right]=\left[\begin{array}{c}\text { Rate of heat loss } \\ \text { from PV module to } \\ \text { air as the top loss }\end{array}\right]+\left[\begin{array}{c}\text { Rate of heat loss from } \\ \text { pv module to } \\ \text { back surface/tedlar }\end{array}\right]+$ $\left[\begin{array}{c}\text { rate of Electricity } \\ \text { produced }\end{array}\right]$. 
International Journal of Mathematical, Engineering and Management Sciences

Vol. 4, No. 2, 460-470, 2019

https://dx.doi.org/10.33889/IJMEMS.2019.4.2-038

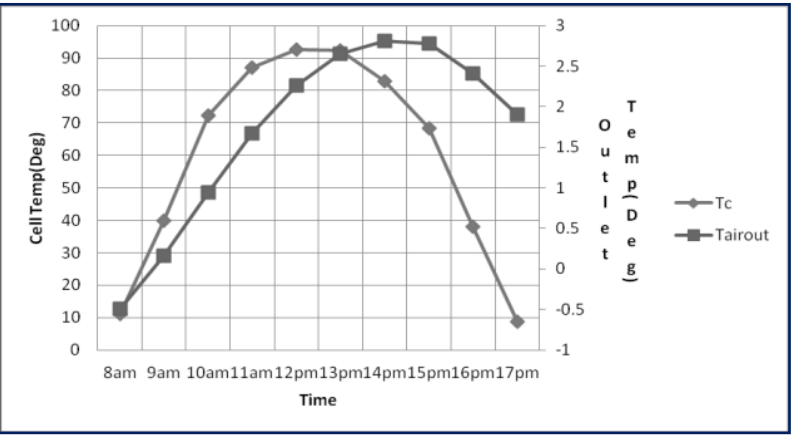

Figure 3. Comparative study of temperature between cell and duct outlet

$\tau_{g}\left[\alpha_{c} \beta_{c}+\left(1-\beta_{c}\right) \alpha_{T}\right] I(t) b d x=\left[U_{T}\left(T_{c}-T_{a}\right)+h_{T}\left(T_{c}-T_{b s}\right)\right] b d x+\eta_{c a} I(t) b d x$

Simplifying

$T_{c}=\frac{h_{T} T_{b s}+U_{T} T_{a}+I(t)(\alpha \tau)_{e f f}}{U_{T}+h_{T}}$

For tedlar of proposed model, Energy balance can be derived as,

$\left[\begin{array}{c}\text { Rate of heat gain from } \\ \text { PV module to tedlar }\end{array}\right]=\left[\begin{array}{c}\text { Rate of heat loss from tedlar to } \\ \text { air side in the duct }\end{array}\right]$

$h_{T}\left(T_{c}-T_{b s}\right) b d x=h_{a i r}\left(T_{b s}-T_{a i r}\right) b d x$

Substituting Tc in Eq. (11)

$T_{b s}=\frac{h_{a i r} T_{a i r}+U_{t T} T_{a}+h_{\rho 1} I(t)(\alpha \tau)_{e f f}}{U_{t T}+h_{a i r}}$

Energy balance of air flowing in the duct of the BIPVT system is given by,

$\left[\begin{array}{c}\text { Rate of heat received from tedlar } \\ \text { to air side in the duct }\end{array}\right]=\left[\begin{array}{c}\text { Rate of heat gain by air } \\ \text { flowing in duct }\end{array}\right]+$

$\left[\begin{array}{c}\text { Rate of heat loss from air } \\ \text { through insulation }\end{array}\right]$

$h_{a i r}\left(T_{b s}-T_{a i r}\right) b d x=M_{a i r} C_{a i r}\left(\frac{d T_{a i r}}{d x}\right) d x+U_{b b}\left(T_{a i r}-T_{a r}\right) b d x$

On substituting $\mathrm{T}_{\mathrm{bs}}$ from Eqn (12) to Eqn (13) we have

$h_{\text {air }}\left[\frac{h_{\rho 1} h_{\rho 2} I(t)(\alpha \tau)_{e f f}-U_{t T}\left(T_{a i r}-T_{c}\right)}{U_{t T} h_{a i r}}\right] b d x=M_{\text {air }} C_{\text {air }}\left(\frac{d T_{\text {air }}}{d x}\right) d x+U_{b b}\left(T_{a i r}-T_{a r}\right) b d x$ 
International Journal of Mathematical, Engineering and Management Sciences

Vol. 4, No. 2, 460-470, 2019

https://dx.doi.org/10.33889/IJMEMS.2019.4.2-038

By $\mathrm{T}_{\text {air }}=\mathrm{T}_{\mathrm{ar}}, \mathrm{T}_{\text {air }}=\mathrm{T}_{\text {airout }}$.

The temperature at the output of duct for length L can be derived as,

$$
\begin{aligned}
& T_{\text {airout }}=\left[\frac{U_{b b} T_{a r}+U_{t a i r} T_{a}+h_{\rho 1} h_{\rho 2} I(t)(\alpha \tau)_{e f f}}{U_{t i}}\right]\left(1-e^{-\frac{b U_{t i} L}{M_{a i r} C_{a i r}}}\right)+T_{a r} e^{-\frac{b U_{t i} L}{M_{a i r} C_{a i r}}} \\
& T_{\text {air }}=\left[\frac{U_{b b} T_{a r}+U_{t a i r} T_{a}+h_{\rho 1} h_{\rho 2} I(t)(\alpha \tau)_{e f f}}{U_{t i}}\right]\left(1-\frac{1-e^{-\frac{b U_{t i} L}{M_{a i r} C_{a i r}}}}{\left(\frac{b U_{t i} L}{M_{a i r} C_{a i r}}\right.}\right)+T_{a r} \frac{1-e^{-\frac{b U_{t i} L}{M_{a i r} C_{a i r}}}}{\frac{b U_{t i} L^{L}}{M_{a i r} C_{a i r}}}
\end{aligned}
$$

For $\eta_{\mathrm{pv}}$ row of the system the overall thermal energy can be derived as,

$Q_{u}=n_{p v} * M_{\text {air }} C_{\text {air }}\left(T_{\text {airout }}-T_{\text {ar }}\right)$

For heating of space of the building the energy balance equation can be derived as,

$$
\begin{aligned}
& n_{p v} * M_{\text {air }} C_{\text {air }}\left[\frac{U_{b b} T_{r}+U_{t a i r} T_{a}+h_{\rho 1} h_{\rho 2} I(t)(\alpha \tau)_{e f f}}{U_{t i}}-T_{a r}\right] *\left(1-e^{-\frac{b U_{t i} L}{M_{a i r} C_{a i r}}}\right)+U_{b b}\left(T_{a i r}+\right. \\
& \left.T_{a r}\right) A_{\text {roof }}=M_{r} C_{\text {air }}\left(\frac{d T_{r}}{d t}\right)+(U A)_{t}\left(T_{a r}-T_{a}\right)+0.33 N_{o} V\left(T_{a r}-T_{a}\right)
\end{aligned}
$$

Table 3. Variation of temperature at different places

\begin{tabular}{|c|c|c|c|}
\hline Tc & Tair(duct) & Tairout (duct outlet) & T $_{\text {ar }}(\mathbf{r o o m})$ \\
\hline 11.0321 & -0.5437 & -0.4915 & -0.5959 \\
\hline 39.742 & -0.0194 & 0.1598 & -0.1986 \\
\hline 72.298 & 0.6211 & 0.9442 & 0.298 \\
\hline 87.1728 & 1.281 & 1.6682 & 0.8939 \\
\hline 92.7663 & 1.8499 & 2.2598 & 1.4401 \\
\hline 92.2978 & 2.2433 & 2.6493 & 1.8374 \\
\hline 82.8908 & 2.448 & 2.8109 & 2.0857 \\
\hline 68.2848 & 2.4816 & 2.7782 & 2.185 \\
\hline 38.0957 & 2.2473 & 2.4089 & 2.0857 \\
\hline 8.664 & 1.868 & 1.8986 & 1.8374 \\
\hline
\end{tabular}

Table 4. Variation of efficiency w.r.t temp

\begin{tabular}{|c|c|c|}
\hline Time & Tc (degree) Cell temp & Electrical Efficiency (\%) \\
\hline $8 \mathrm{am}$ & 11.0321 & 17.0057 \\
\hline $9 \mathrm{am}$ & 39.742 & 14.9386 \\
\hline $10 \mathrm{am}$ & 72.298 & 12.5945 \\
\hline $11 \mathrm{am}$ & 87.1728 & 11.5236 \\
\hline $12 \mathrm{pm}$ & 92.7663 & 11.1208 \\
\hline $13 \mathrm{pm}$ & 92.2978 & 11.1546 \\
\hline $14 \mathrm{pm}$ & 82.8908 & 11.8319 \\
\hline $15 \mathrm{pm}$ & 68.2848 & 12.8835 \\
\hline $16 \mathrm{pm}$ & 38.0957 & 15.0571 \\
\hline $17 \mathrm{pm}$ & 8.664 & 17.1764 \\
\hline
\end{tabular}


International Journal of Mathematical, Engineering and Management Sciences

Vol. 4, No. 2, 460-470, 2019

https://dx.doi.org/10.33889/IJMEMS.2019.4.2-038

Temperature of air inside the room can be derived as

$$
\begin{aligned}
& T_{a r}=\frac{f(t)}{a}\left(1-e^{-a t}\right)+T_{r i} e^{-a t} \\
& f(t)=\frac{1}{M_{r} C_{\text {air }}}\left[\left\{(U A)_{t} 0.33 N_{o} V\right\} T_{a}+\left\{\eta_{p v} M_{\text {air }} C_{\text {air }}\left[\frac{U_{\text {tair }} T_{a}+h_{\rho 1} h_{\rho 2} I(t)(\alpha \tau)_{e f f}}{U_{t i}}\right](1-\right.\right. \\
& \left.\left.\left.e^{\frac{-b U_{t i} L}{M_{\text {air }} C_{\text {air }}}}\right)\right\}+U_{b b}\left\{\frac{U_{\text {tair }} T_{a}+h_{\rho 1} h_{\rho 2} I(t)(\alpha \tau)_{e f f}}{U_{t i}}\right\}\left(1-\frac{1-e^{\frac{-b U_{t i} L}{M_{a i r} C_{a i r}}}}{\frac{b U_{t i} L}{M_{\text {air }} C_{\text {air }}}}\right) A_{\text {roof }}\right]
\end{aligned}
$$

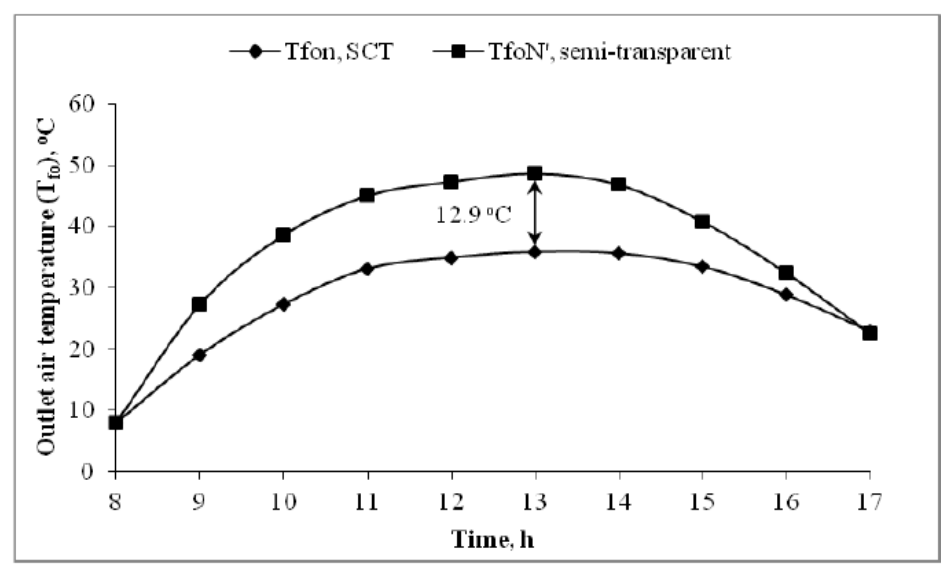

Figure 4. Variations of room air temperature w.r.t time

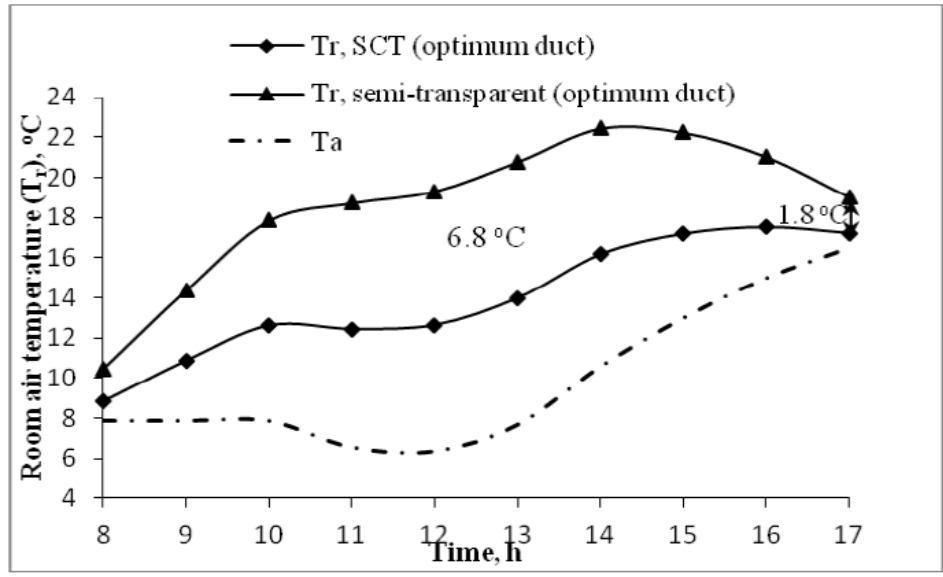

Figure 5. Variation of thermal energy w.r.t number of air changes

Figure 5 describes the variation of thermal energy w.r.t. number of air changes. 
International Journal of Mathematical, Engineering and Management Sciences

Vol. 4, No. 2, 460-470, 2019

https://dx.doi.org/10.33889/IJMEMS.2019.4.2-038

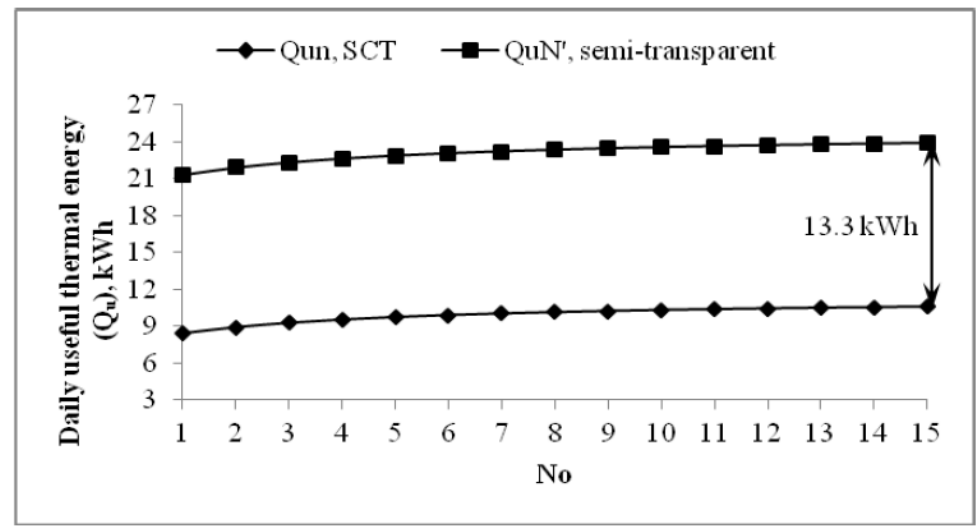

Figure 6. Variation of thermal energy w.r.t number of air changes

In case of semi-transparent PVT roof, the maximum room air temperature and maximum daily useful heat gain for a typical day of January is higher by $6.8^{\circ} \mathrm{C}$. The efficiency, exergy, thermal and electrical gain have been calculated from temperature at different places from Table 3 and Table 4 after changing the parameters related to the system. The values have been compared with the previous one and percentage change is calculated with the use of "MATLAB-13". The air is blown at a pace of $1.5 \mathrm{~kg} / \mathrm{sec}$ inside the duct to get maximum efficiency.

\section{Results and Discussion}

- Figure 2 shows that even if the cell temp dies out at $5 \mathrm{pm}$ there is presence of duct temperature which indicates the efficiency of the module.

- A comparison has been made between electrical efficiency and exergy efficiency which shows that after combining the electrical and thermal energy the net electrical efficiency increases from $17.1 \%$ to $18.4 \%$ which can be shown from Figure 3.

- At $12.9 \%$ more outlet temperature of semi-transparent PVT it has an edge as compared to other system, which can be shown from Figure 4.

- At $13.3 \mathrm{kWh}$, semi-transparent system has more daily useful heat gain as compared to SCT roof, which can be seen from Figure 6.

- The Figure 7 shows the overall thermal electrical gain in KWH.

- Figure 8 gives better idea that present system is best suited for Srinagar climatic condition as compared to Delhi. 
International Journal of Mathematical, Engineering and Management Sciences

Vol. 4, No. 2, 460-470, 2019

https://dx.doi.org/10.33889/IJMEMS.2019.4.2-038

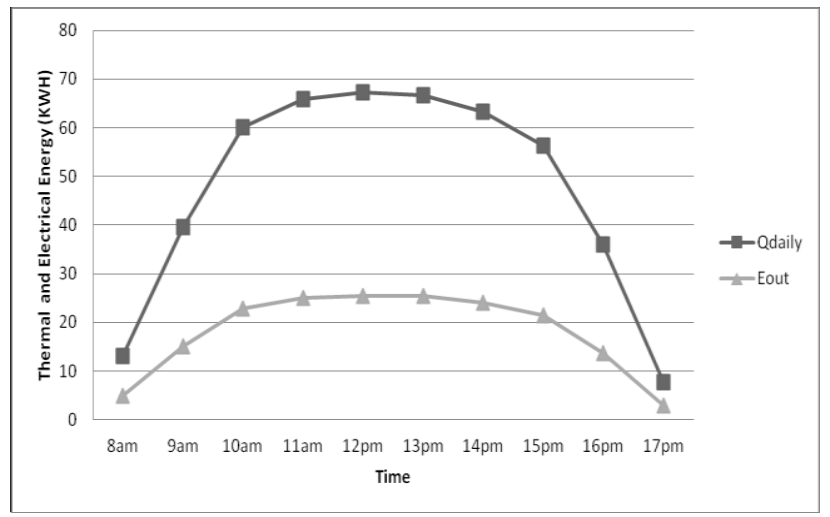

Figure 7: Variation of Electrical and Energy efficiency with Time

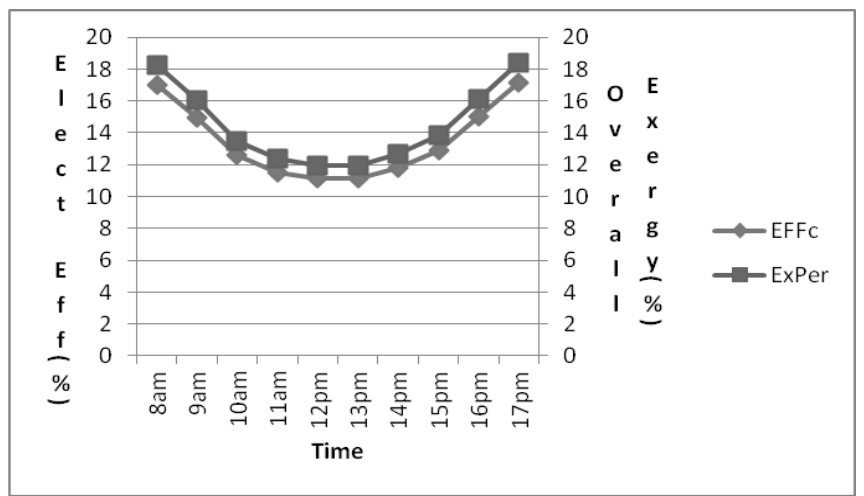

Figure 8. Variation of Electrical and Exergy Efficiency w.r.t time

\section{Conclusion}

Data shows that the solar intensity is maximum in Srinagar at $1 \mathrm{pm}$ in the month of January. If for the same system a comparison is made then it has been concluded that Srinagar gives better result as compared to Delhi, that is, almost $2 \%$ more efficient. Comparison has also been made to know about the room temperature, duct and the outlet in Table 3 and Table 4.

The present system produces almost $67 \mathrm{KWh}$ thermal energy per day as compared to $51 \mathrm{KWh}$ of previous system (Figure 7). As far as total electrical energy is concerned it produces $25 \mathrm{KWh}$ per day from 8 to $5 \mathrm{pm}$ as compared to $23 \mathrm{KWh}$ of previous system. As far as efficiency is concerned this system produces $17.1 \%$ of electrical efficiency and overall exergy of $18.4 \%$ as compared to $16 \%$ and $17 \%$ of previous system. 
International Journal of Mathematical, Engineering and Management Sciences

Vol. 4, No. 2, 460-470, 2019

https://dx.doi.org/10.33889/IJMEMS.2019.4.2-038

\section{Appendix}

$$
\begin{aligned}
& (\alpha \tau)_{e f f}=\tau_{g}\left[\alpha_{c} \beta_{c}+\left(1-\beta_{c}\right) \alpha_{T}\right]-\eta_{c}, U_{T}=\left(\frac{\mathrm{Lg}}{\mathrm{Kg}}+\frac{1}{\mathrm{ho}}\right)^{-1}, h_{T}=\left(\frac{L_{T}}{K_{T}}\right)^{-1}, h_{\rho 1}=\frac{h_{T}}{U_{T+h_{T}}}, \\
& U_{t T}=\frac{U_{T} * h_{T}}{U_{T+h_{T}}}=\left(\frac{1}{h_{T}}+\frac{1}{U_{T}}\right)^{-1}, U_{b b}=\left(\frac{1}{h_{\text {air }}}+\frac{\mathrm{Li}}{K_{i}}+\frac{1}{h_{r}}\right)^{-1}, h_{\rho 2}=\frac{h_{\text {air }}}{U_{t T+h_{\text {air }}}}, U_{\text {tair }}=\left(\frac{1}{h_{\text {air }}}+\frac{1}{U_{t T}}\right)^{-1}, \\
& \mathrm{U}_{\mathrm{L}}=\left(\mathrm{U}_{\mathrm{bb}}+\mathrm{U}_{\text {tair }}\right),(\mathrm{UA})_{\mathrm{t}}=(\mathrm{UA})_{\mathrm{t} \_ \text {wall }}+(\mathrm{UA})_{\mathrm{t} \_ \text {win }}+(\mathrm{UA})_{\mathrm{t} \_\mathrm{dr},},(\mathrm{UA})_{\mathrm{t} \_\mathrm{dr}}=\frac{A_{d}}{\left(\frac{1}{h_{o}}+\frac{1}{h_{r}}+\frac{L_{d}}{K_{d}}\right)},
\end{aligned}
$$

$(\mathrm{UA})_{\mathrm{t} \_ \text {win }}=\frac{A_{\text {win }}}{\left(\frac{1}{h_{o}}+\frac{1}{h_{r}}+\frac{L_{\text {win }}}{K_{\text {win }}}\right)},(\mathrm{UA})_{\mathrm{t} \_ \text {wall }}=\frac{A_{\text {wall }}}{\left(\frac{1}{h_{o}}+\frac{1}{h_{r}}+\frac{L_{\text {wall }}}{K_{\text {wall }}}\right)}$.

\section{Conflict of Interest}

The authors confirm that there is no conflict of interest to declare for this publication as the work is original.

\section{Acknowledgements}

The authors would like to express their sincere thanks to the referee and for their valuable suggestions towards the improvement of the paper. The authors are really thankful for the support from Basant Agarwal, C. S. Rajoria whose papers provided lots of information regarding design and make the proposed system possible. The Indian Meteorology Department (IMD), Pune has a major role in providing data related to temperature of different cities.

\section{References}

Agarwal, B., \& Tiwari, G. N.(2009). Building integrated photovoltaic thermal systems: for sustainable developments. Royal Society of Chemistry, Delhi. ISBN: 978-1-84973-090-7.

Agrawal, B., \& Tiwari, G. N. (2010). Optimizing the energy and exergy of building integrated photovoltaic thermal (BIPVT) systems under cold climatic conditions. Applied Energy, 87(2), 417-426.

Agrawal, S., \& Tiwari, G. N., (2012). Exergoeconomic analysis of glazed hybrid photovoltaic thermal module air collector. Solar Energy, 86(9), 2826-2838.

He, W., Chow, T. T., Ji, J., Lu, J., Pei, G., \& Chan, L. S. (2006). Hybrid photovoltaic and thermal solar collector designed for natural circulation of water. Applied Energy, 83(3), 199-210.

Kim, J. H., \& Kim, J. T., (2012). A simulation study of air-type building-integrated photovoltaic-thermal system, Energy Procedia, 30, 1016-1024.

Loferski, J. J., Ahmad, J. M., \& Pandey, A. (1998). Performance of photovoltaic cells incorporated into unique hybrid photovoltaic/thermal panels of a $2.8 \mathrm{KW}$ residential solar energy conversion system. In Proc. of the 1988 Annual Meeting, American Solar Energy Society, Cambridge, Massachusetts, 427432.

Rajoria, C. S., Agrawal, S., \& Tiwari, G. N. (2012). Overall thermal energy and exergy analysis of hybrid photovoltaic thermal array. Solar Energy, 86(5), 1531-1538.

Rajoria, C. S., Agrawal, S., \& Tiwari, G. N. (2013). Exergetic and enviroeconomic analysis of novel hybrid PVT array. Solar Energy, 88, 110-119. 
International Journal of Mathematical, Engineering and Management Sciences

Vol. 4, No. 2, 460-470, 2019

https://dx.doi.org/10.33889/IJMEMS.2019.4.2-038

Singh, S., Agrawal, S., Tiwari, A., Al-Helal, I. M., \& Avasthi, D. V. (2015). Modeling and parameter optimization of hybrid single channel photovoltaic thermal module using genetic algorithms. Solar Energy, 113, 78-87.

Vats, K., \& Tiwari, G. N. (2012). Energy and exergy analysis of a building integrated semitransparent photovoltaic thermal (BISPVT) system. Applied Energy, 96, 409-416.

Zondag, H. A., de Vries, D. D., Van Helden, W. G. J., van Zolingen, R. C., \& Van Steenhoven, A. A. (2002). The thermal and electrical yield of a PV-thermal collector. Solar Energy, 72(2), 113-128. (c) 1 Original content of this work is copyright () International Journal of Mathematical, Engineering and Management Sciences. All rights reserved.
Except of uses under a Creative Commons Attribution 4.0 International (CC BY 4.0) license at https://creativecommons.org/licenses/by/4.0/ 